istry. The Bureau has also more recently (May 1958) commenced the issue of a monthly guide, Express Contents, containing, in English translation, the tables of contents of all Soviet journals being translated and published regularly by the Bureau, other firms and learned societies. The estimated date of publication of the English translation of the particular issue of the journal is given, together with the name and address of the organization from whom the translation may be obtained and the subscription price or individual cost. The first issue of Express Contents includes all the January and February material received by the Bureau by March 30, 1958 ; the June issue will contain March-April material; and the July issue May material. A table of contents of all the 1957 issues of the journals will be published as a single volume in June. In the United States there is a large programme of translation from the Russian, which was the subject of an article by $R$. E. O'Dette (programme director of the Foreign Science Information Programme of the National Science Foundation, Washington, D.C.) entitled "Russian Translation" in Science $(125,579 ; 1957)$, where a detailed guide is given to what was being done and planned, and by whom. A more up-to-date statement and, in particular, one relating to the United Kingdom would be most valuable.

\section{Library Science}

UNDER the title "Lrbrary Science and Scientific Method", Chapter 8 of the second edition of Dr. S. R. Ranganathan's "The Five Laws of Library Science" has been issued as a separate reprint (pp. ii + 355-424. Madras Library Association, 1957). Boginning with a brief discussion of the nature of science and scientific method, Dr. Ranganathan stoutly and skilfully defends his claim for the term 'library science'. Although the difference between seience and technology scarcely emerges, Dr. Ranganathan advances ample evidence to justify the consideration of library science as an academic discipline on a par with much that is taught in a university or college of technology. Following further exposition of his five laws of library science, Dr. Ranganathan reviews briefly some of their implications to-day and more especially the opportunities for research in library work, concluding with some account of developments in India and of the Division of Libraries in the United Nations Educational, Scientific and Cultural Organization.

\section{Preparation of Skeletons}

IN the Museums Journal for March 1958, Dr. D. H. Thompsett, prosector of the Museum of Anatomy at the Royal College of Surgeons, describes work he has undertaken in collaboration with Mr. C. G. Bush, articulator. The work is divided into two stages, namely, the preparation of the bones and the articulation of the skeleton. The former stage may be effected either by simmering the bones in water between $60^{\circ}$ and $65^{\circ} \mathrm{C}$. for a period which varies according to the size of the animal, or soaking the bones in colder water at about $30^{\circ} \mathrm{C}$. The skeleton is then disarticulated into six units consisting, respectively, of head, trunk, ribs and pelvis, the two forelimbs, each with half the pectoral girdle, and the two hind limbs. The bones are soaked in a 2 per cent solution of caustic soda to facilitate cleaning and bleached by hydrogen peroxide. Grease stains may be removed by trichlorethylene. In articulation the vertebræ and thoracid cage are dealt with first, and the subsequent stages are fully described. An attractive glossy finish resembling polished ivory can be given to the skeleton by spraying it with transparent synthetic resin.

\section{Fusarium oxysporum as a Soil Saprophyte}

THE status of Frusarium oxysporum Schl.-the pathogen of vascular wilt disease of the oil palm-as a saprophyte in the soil has been examined by D. Park (Annals of Botany, N.S., 22, 19 ; 1958). This fungus was present in soil from wilt-free areas of oil palm plantations as well as in soil about wiltdiseased palms. Hyphal fusions between soil isolates and isolates from wilted palms could be demonstrated. The fungus persisted for periods of at least one year in naturally infested soils under a variety of moisture conditions ; it also survived in inoculated alien soils for at least one year. Soil forms of the fungus had a high competitive saprophytic ability, competitively colonizing sterilized soils and sand, and organic materials added to soils and mixed cultures. The pathogenic isolate, as well as the soil isolates, exhibited characters belonging to soilinhabiting fungi, namely, continued persistence in soil : tolerance, in respect of growth and reproduction, to antagonism : and the ability competitively to colonize dead organic material in soils. The pathogenic form is considered to be a soil inhabitant.

\section{A Transistor Thyratron}

AN important new device recently made available by the General Electric Company of America is the silicon 'Unijunction' transistor, which is a semiconductor equivalent of the controlled-grid thyratron. It is a three-terminal device, hermetically sealed, with a stable $n$-type negative resistance characteristic over a wide range of temperature. The $n$-type silicon bar is mounted between two ohmic base contacts with a $p$-type emitter near the second base contact. The high peak-current rating makes the device useful in medium power switching and oscillator applications, where it can serve the purpose of two conventional silicon transistors. Some of the applications for which the 'Unijunction' transistor is particularly recommended are sawtooth generators, pulse generators, pulse-rate modulators, pulse amplifiers, multivibrators, flip-flops and time-delay circuits.

\section{Linnean Society of London : Officers}

Ar the anniversary meeting of the Linnean Society of London, held on May 24, the following were elected officers for the session 1958-59: President, Dr. C. F. A. Pantin; Treasurer, The Earl of Cranbrook; Secretaries, Assistant Prof. H. R. Hewer (zoology) and Dr. C. R. Metcalfe (botany). Mr. J. P. M. Brenan, The Earl of Cranbrook, Dr. J. L. Harley, Dr. W. G. Templeman and Dr. H. G. Vevers were elected new members of the Council. Dr. Franciseo d'Ascençaõ Mendonça and Prof. Henri Humbert were elected Foreign Members and Mr. Henry Ashley Toombs and Mr. John Clegg were elected Associates honoris causa.

\section{Publication of the Carlsberg Laboratory}

SrNCE 1934, the Comptes rendus de Laboratoire Carlsberg has been published in two series, the Série chimique and the Série physiologique. In view of the fact that the majority of subscribers receive both series, it has been decided to stop dividing the journal. Thus, Vol. 26 is to be the last of Serie physiologique, and Vol. 30 will be the last of Série 